\title{
Waste-to-wealth: The economic reasons for replacing waste-to-energy with the circular economy of municipal solid waste
}

\author{
Mario Pagliaro \\ Istituto per lo Studio dei Materiali Nanostrutturati, CNR, via U. La Malfa 153, 90146 Palermo, Italy; E-mail: mario.pagliaro@cnr.it
}

\begin{abstract}
Sharing the same raw material, recycling and composting are in direct conflict with incineration of municipal solid waste in combined heath and power plants. Indeed, waste-to-energy plants in regions with high recycling rates import urban waste from other countries to use otherwise unused capacity, and raise revenues. Using the case of Italy's second largest and economically most developed region, I discuss the economic viability of municipal solid waste incineration to produce electricity and heath in the context of the increasing role of electricity production from renewable energy sources as well as of the emerging mass-scale uptake of bioplastics. Four lessons and three guidelines aimed to local authorities and policy makers emerge from the present study.
\end{abstract}

Keywords:

Recycling

Composting

Waste-to-energy

Incineration

Municipal solid waste

Circular economy

Green jobs

\section{Introduction}

Chiefly as a consequence of ingestion as the dominant exposure pathway for the public, the impact of urban waste incineration on human health is significant and of broad scope, including diverse adverse health effects, from infant deaths and miscarriage. ${ }^{1}$ Furthermore, each municipal solid waste (MSW) waste-to-energy plant generates an highly toxic residue (fly ash) rich in heavy metals and hazardous organochlorines formed upon the partly removal of toxic compounds in the incinerator gas effluents.

Originally introduced in Great Britain in the 1870s, when wood and biomass residues were abundant in urban waste, incineration has been along with disposal in sanitary landfills the main method of MSW disposal used across nations. The first plants in Britain were already able to burn waste at temperatures high enough to allow self-sustained combustion (i.e., requiring no coal or wood) with minimal odors. ${ }^{3}$

Walsh has nicely recounted how refuse incineration in New York City where the first municipal incinerator was built in 1908, ended in the early 1990s with the voluntary closure of the three remaining municipal waste-to-energy plants due to absence of air pollution control equipment which incinerators "vulnerable to stricter government emissions limits, ultimately resulting in their premature closure and the decline of incineration as a waste management practice in the city". 3

Today, incineration of urban waste in combined heat and power (CHP) plants often using the hot water with district heating systems ${ }^{4}$ is widely employed across the world.

In the course of the last three decades (1990-2019), however, urban waste recycling has become so widespread and successful that several world's cities and regions reached and even surpassed 70 per cent recycling rates, making urban waste increasingly unavailable for incineration.

This further worsens the poor economic sustainability of burning MSW in waste-to-energy plants which traditionally has required generous public incentives in the form of prolonged (20 or even 30 year) power purchase agreements for electricity fed into the grid paid with generous tariffs (feed-intariff) with waste-to-energy electricity formally classified as "renewable". 6

In this succinct study, rather than using abstract models, I use real data mostly from Italy but also from other countries to show the economic reasons for replacing waste-to-energy with the circular economy of municipal solid waste.

In Italy, I further focus on the second largest and most economically developed and populated region (Lombardia) hosting 13 of Italy's 39 incineritors.

\section{Results and Discussion}

In 2018, Lombardia collected for recycling $61.7 \%$ of municipal urban waste, whereas $25.4 \%$ of urban waste was incinerated. ${ }^{5}$ However, 400,000 tonnes out of 2.2 million tonnes MSW burned in the same year were imported from other Italy's regions.

From the energy viewpoint, Morris has shown in 1996 that while recycling conserves energy that would otherwise be expended extracting virgin raw materials from the natural environment, burning refuse in a waste-to-energy plant equates to waste energy for 24 out of 25 typical municipal solid waste materials.'

Lombardia in 2018 hosted 64 composting plants, 6 aerobic and anaerobic integrated treatment, and 8 anaerobic digestion plants. ${ }^{8}$ Together, the aforementioned plants treated, 
respectively, 1,004,723 t $+762,522 \mathrm{t}+233,683 \mathrm{t}$ namely an overall amount of 2,000,928 tonnes. In the same year, the region's cities sent 1,944,000 tonnes of residual MSW produced in Lombardia to the region's waste-to-energy plants. ${ }^{8}$

The cost beared by Lombardia's cities and other Italy's regions delivering their non recycled waste to Lombardia's incineritors in 2018 varied between $€ 100 / \mathrm{t}$ and $€ 150 / \mathrm{t}^{9}$ This led for example a 40,000 inhabitant Lombardia's city (Desio) to launch even the separate collection for recycling of diapers (which, alone, amount to over $15 \%$ of the previously non recyclable waste). ${ }^{9}$ Thanks to this and to other improvements and innovations in the collection of recyclable materials, in year 2018 the recycling rate in Desio reached 78.31\%, from $61.81 \%$ in $2017 .^{10}$

In this way, having reduced the amount of waste sent to waste-to-energy plants, the average waste tax rate paid by the average family in Desio diminished by $€ 6,{ }^{10}$ and this regardless of the lower prices paid for collected paper and glass. ${ }^{11}$

In general, the more cities in Lombardia progress towards achieving high recycling rates transforming waste into wealth, the less urban waste becomes available for burning.

Urban waste is far from being a "renewable" energy source, and in Italy its combustion to produce power cannnot be any longer subsidized as it happened for decades in Italy (and in virtually all countries) ${ }^{12}$ where waste-to-energy plants are installed. In closer detail, as of 2017 in Italy only 6 out of 39 waste-to-energy plants still benefited from the feed-in-tariff incentives. $^{13}$

At the same time, the increasing share of renewable energy generation lowers the wholesale price of electricity in all countries (including Italy) $)^{14}$ with a significant penetration of power generation from renewable energy sources.

The fact that waste-to-energy plants need large amounts of municipal waste to be economically viable, including plants using state-of-the-art combustion technology, is further demonstrated by the $€ 540$ million plant waste-to-energy plant near Copenhagen (Amager Bakke) which started operation on March $2017 .{ }^{15}$

Owned by five municipalities, in less than a year the value of the company managing the new plant "plummeted from plus 2.3 billion DKK to a negative 200 million DKK, corresponding to an overall loss of 2.5 billion DKK, or roughly 330 million euro" due to the fact "that there was not enough garbage in the city to power the over-sized plant”. ${ }^{16}$

Similarly, to use otherwise unused capacity, increase revenues as well as to increase the low calorific content of MSW devoid of paper and plastics, since 2011 several countries with high recycling rates including Germany, the Netherlands, and Sweden started importing waste shipped from eastern and southern Europe. ${ }^{17}$

Indeed, the analysis of municipal waste delivered to incinerators shows that a significant fraction $(40 \%-60 \%)$ is recyclable or compostable. ${ }^{18}$

Similarly, recent analysis of municipal solid waste in the city of Johannesburg revealed that plastics and organic wastes constitute the highest waste content (28\% plastics and 28\% organic waste in the round collected refuse) almost independently of the season. ${ }^{19}$

However, driven by large societal and environmental megatrends, after two decades of false starts a large bioplastics industry is finally emerging across the world. ${ }^{20}$ This will inevitably further lower the amount of post consumer plastic waste available for burning at waste-to-energy plants.

\section{Conclusions and Recommendations}

Four lessons and three guidelines for local authorities and policy makers therefore emerge as main outcomes of the present study.

First, policy makers should be aware that recycling and composting are not complementary, but rather in direct conflict with incineration as all these technologies compete for the same raw material: municipal solid waste.

Second, policy makers should be aware that the low and decreasing wholesale price of electricity due to increasing penetration of power generation from renewable energy sources, ${ }^{14}$ makes electricity generation by burning municipal solid waste ever less convenient, worsening the already poor economic viability of waste to energy plants.

Third, policy makers should be aware that the rapid emergence of bioplastics started with the introduction of biodegradable plastic bags and now expanding to high value added plastics, ${ }^{20}$ will rapidly lower the availability of plastics in MSW further impoverishing its already low calorific value. ${ }^{7}$

Table 1. Jobs created by management activity in the circular economy of selected materials in municipal solid waste. [Adapted from Ref.21, with kind permission of the Tellus Institute]

\begin{tabular}{|c|c|c|c|c|}
\hline Material & $\begin{array}{l}\text { Collection } \\
\text { (in 2008) }\end{array}$ & Processing & Manufacturing & $\begin{array}{l}\text { Reuse/ } \\
\text { Remanufacture }\end{array}$ \\
\hline & $\begin{array}{l}\text { Jobs per } \\
1000 t\end{array}$ & $\begin{array}{l}\text { Jobs per } \\
1000 t\end{array}$ & $\begin{array}{l}\text { Jobs per } 1000 \\
t\end{array}$ & Jobs per $1000 t$ \\
\hline $\begin{array}{l}\text { Paper } \\
\text { and } \\
\text { cardboard }\end{array}$ & 1.67 & 2.00 & 4.16 & $\mathrm{~N} / \mathrm{A}$ \\
\hline Glass & 1.67 & 2.00 & 7.85 & 7.35 \\
\hline Ferrous & 1.67 & 2.00 & 4.12 & 20.00 \\
\hline Aluminum & 1.67 & 2.00 & 17.63 & 20.00 \\
\hline $\begin{array}{l}\text { Non } \\
\text { ferrous }\end{array}$ & 1.67 & 2.00 & 17.63 & 20.00 \\
\hline Plastics & 1.67 & 2.00 & 10.30 & 20.00 \\
\hline $\begin{array}{l}\text { Rubber } \\
\text { and } \\
\text { leather }\end{array}$ & 1.67 & 2.00 & 9.24 & 7.35 \\
\hline Textiles & 1.67 & 2.00 & 2.50 & 7.35 \\
\hline Wood & 1.67 & 2.00 & 2.80 & 2.80 \\
\hline
\end{tabular}

Fourth, policy makers need to be aware that waste-to-energy plants using capital intensive equipment able to handle large tonnages with few employees create a limited number of jobs (0.1 jobs per 1,000 tonnes). ${ }^{21}$ On the other hand, the circular economy of municipal waste starting with recyclable material collection from locations such as households, drop-off points, offices and firms is a powerful way to create jobs, especially in manufacturing and in reuse and remanufacturing activity (Table 1). ${ }^{21}$

Three guidelines are suggested to guide effective policy action in transitioning from waste-to-energy to waste-to-wealth based on today's circular economy technologies and methods applied to municipal solid waste management.

First, inspired by the key principle of the circular economy to reduce, reuse, recycle and recover waste (the 4R concepts), ${ }^{22}$ local authorities and policy makers should refrain from signing long-term contracts to supply municipal waste to waste-toenergy plants, and rather focus efforts to maximize recycling rates for their MSW turned from a cost item (waste) into an earning item (wealth). 
Second, consistent with the high recycling rates achieved in a few years in many world's regions currently exceeding $70 \%$ and even $80 \%$ rates, policy makers should promote the development of a technologically advanced, second generation plastics recycling industry whose best companies, thanks to increased investment in waste collection, sorting, and recycling technologies are already able to recycle plastics to near virgin purity. $^{23}$

Finally, aware that management education plays a key role in the transition to the circular bioeconomy, ${ }^{24}$ policy makers and local authorities should deploy new educational activities to convert urban waste management companies from companies collecting waste for incineration or sanitary landfill, into circular economy organizations operating in the materials value chain steps of collecting and sorting, but also in the key steps of manufacturing and reuse and remanufacturing. ${ }^{21}$

\section{Author ORCID information}

\section{Mario Pagliaro: 0000-0002-5096-329X}

\section{Conflicts of Interest}

The author declares no conflict of interest.

\section{References}

1. P. W. Tait, J. Brew, A. Che, A. Costanzo, A. Danyluk, M. Davi, A. Khalaf, K. McMahon, A. Watson, K. Rowcliff, D. Bowles, The health impacts of waste incineration: a systematic review, Aust. NZ. J. Public Health 2020, 44, 40.

2. E. I. Diaz-Loya, E. N. Allouche, S. Eklund, A. R. Joshi, K. Kupwade-Patil, Toxicity mitigation and solidification of municipal solid waste incinerator fly ash using alkaline activated coal ash, Waste Manage. 2012, 32, 1521-1527

3. D. C. Walsh, The Evolution of Refuse Incineration, Environ. Sci Technol. 2002, 36, 316A-322A.

4. O. Eriksson, G. Finnveden, Energy Recovery from Waste Incineration-The Importance of Technology Data and System Boundaries on $\mathrm{CO}_{2}$ Emissions, Energies 2017, 10(4), 539.

5. Regione Lombardia, Rifiuti. Cattaneo: in Lombardia tassa più bassa rispetto a media italiana, 20 November 2019. See at the

URL:

www.regione.lombardia.it/wps/portal/istituzionale/HP/lombard ia-notizie/DettaglioNews/2019/11-novembre/18-24/cattaneorifiuti-in-lombardia-tassa-piu-bassa/cattaneo-rifiuti-inlombardia-tassa-piu-bassa

6. Inceneritori, in Lombardia 400mila tonnellate di rifiuti dal Sud, Il Giorno, 28 November 2018.

7. J. Morris, Recycling Versus Incineration: An Energy Conservation Analysis, J. Hazard. Mater. 1996, 47, 277.

8. Istituto Superiore per la Protezione e la Ricerca Ambientale, Rifiuti Urbani, Gestione regioni: Riepilogo tutte le tipologie di impianti, Anno 2018, Rome: 2020. See at the URL: www.catasto-

rifiuti.isprambiente.it/index.php?pg=gestregione\&width=1920 \&height $=1080$ \&advice $=$ si

9. Comune di Desio, Pannolini, al via il riciclo, 18 July 2018. See at the URL: www.comune.desio.mb.it/it/news/pannolinial-via-il-riciclo.

10. Rifiuti: a Desio aumenta la differenziata, meno costi per le utenze domestiche, Prima Monza, 19 May 2019. See at the URL: https://primamonza.it/cronaca/rifiuti-a-desio-aumenta-ladifferenziata-meno-costi-per-le-utenze-domestiche/

11. M. Armeli, Smaltimento dei rifiuti, costi alle stele. Proseguire l'impegno sulla differenziata, L'Eco di Bergamo, 17 January 2019. http://www.vcsonline.it/wp-
content/files_mf/1548317233NoiComune1517gen19rifiutiediff er.pdf

12. In the US, for example, where tip fees at incinerators were found to be two to three times higher than comparable recycling or composting fees, as of late 2018, 23 states legally classified incineration as "renewable" in their energy legislation: M. Donahue, Report: Waste Incineration: A Dirty Secret in How States Define Renewable Energy, ilsr.org, 23 December 2018. See at the URL: https://ilsr.org/wasteincineration-renewable-energy/

13. Utilitalia, Rapporto sul Recupero Energetico da rifiuti in Italia, Rome: 2019; pp.108-109.

14. F. Meneguzzo, F. Zabini, R. Ciriminna, M. Pagliaro, Assessment of the Minimum Value of Photovoltaic Electricity in Italy, Energy Sci. Eng. 2014, 2, 94-105.

15. A. Gurzu, Not enough's rotten in the state of Denmark, Politico, 9 September 2019. See at the URL: https://www.politico.eu/article/denmark-garbage-gambleamager-bakke-plant-waste/

16. U. Kohl, The Copenhill Crisis, Master Thesis, Malmo University, 2018.

17. N. Seltenrich, Incineration Versus Recycling: In Europe, A Debate Over Trash, Yale Environment 360, 28 August 2013. See at the URL: https://e360.yale.edu/features/incineration_versus_recycling_i n_europe_a_debate_over_trash

18. Global Alliance for Incinerator Alternatives, Waste Incinerators: Bad News for Recycling and Waste Reduction, October 2013. See at the URL: www.no-burn.org/wpcontent/uploads/Bad-News-for-Recycling-Final.pdf.

19. O. O. Ayeleru, F. N. Okont, F. Ntuli, Municipal solid waste generation and characterization in the City of Johannesburg: A pathway for the implementation of zero waste, Waste Manage. 2018, 79, 87-97.

20. R. Ciriminna, M. Pagliaro, Biodegradable and compostable plastics: A critical perspective on the dawn of their global adoption, ChemistryOpen 2020, 9, 8-13.

21. J. Goldstein, C. Electris, More Jobs, Less Pollution: Growing the Recycling Economy in the U.S., Tellus Institute, Cambridge, MA: 2011. See at the URL: https://www.tellus.org/tellus/publication/more-jobs-lesspollution-growing-the-recycling-economy-in-the-u-s

22. Y. Ruslinda, S. Raharjo, Y. Dewilda, Hidayatullah, R. Aziz, Minimization of household hazardous solid waste (HHSW) with 4R concepts (reduce, reuse, recycle and recovery) in Padang City, Indonesia, IOP Conference Series: Materials Science and Engineering, Volume 602, Conference on Innovation in Technology and Engineering Science 8-9 November 2018, Padang, Indonesia.

23. Research and Markets, Recycled Plastics Market By Type, By Application and By Geography - Global Drivers, Restraints, Opportunities, Trends, and Forecast up to 2025, J. Hazard. Mater, Dublin: 2020.

25. J. Philp, D. Winickoff, Realising the circular bioeconomy, OECD Science, Technology and Industry Policy Papers, 2018, No. 60, OECD Publishing: Paris. 